\title{
Many Roads to Paris: A Comparative Review of Pension Policies in Two OECD Countries
}

\author{
Jacob Assa \\ New School for Social Research, New York, USA \\ E-mail:assaj401@newschool.edu \\ Received April 26, 2011; revised June 23, 2011; accepted July 27, 2011
}

\begin{abstract}
Common (neoliberal) wisdom warns against the detrimental effects of demographic changes and fiscal pressures on traditional (both defined-benefit and public) pensions and urges a paradigm shift towards definedcontribution plans and personal retirement accounts. This paper examines these claims, promoted by the OECD and World Bank, among others, by comparing the experiences of two OECD members-Israel and Ireland. While Ireland, one of the founders of the OECD, has pursued typical neoliberal policies of retrenchment, Israel — the newest member of the OECD — has taken a more sinuous path, reversing some retrenchment and eventually making pensions mandatory and almost doubling employer contributions to them. The outcomes of these policies seem to be far more positive in Israel than in Ireland, both in terms of their effects on retirees and workers, as well as their impact via aggregate demand on the overall economy, particularly in the aftermath of the Great Recession.
\end{abstract}

Keywords: Welfare, Demography, Retirement, Pension

\section{Introduction}

Pension policies are often at the forefront of political and economic debates, even more so now following the largest recession since the Great Depression. Various arguments relating to pension plan sustainability, benefit adequacy, and the relationship between pensions and the overall economy have been made. Among the leading voices in the debate, the Organization for Economic Cooperation and Development (OECD) has usually taken a conservative, neoliberal approach, advocating private savings for retirement, in particular defined-contribution (DC) type plans as well as personal savings accounts, as a magic bullet to cure all pension-related ills. In its various reports, including the three editions of Pensions at a Glance, the OECD has warned of demographic pressures and fiscal imbalances that would cause the traditional defined-benefit (DB) plans and public-pensions schemes to become unsustainable. There has indeed been a shift in many countries, including within the OECD, from DB to DC pensions. Countries have cut benefits, raised retirement ages, and shifted much of the risks of old-age insurance from employers or the state to employees. The OECD and the World Bank suggest that this would stabilize pension funds as well as strengthen the general economy.

The purpose of this paper is to examine these claimsas well as the accompanying policy prescriptions-in light of the evidence, using a comparative study of two different country experiences within the OECD membership. While some countries such as Ireland have indeed followed the narrow (and austere) path to salvation, as it were, others such as Israel-the OECD's newest member-have gone through a more sinuous process, facing various pressures and finding a middle-ground with the active involvement of labor. There are indeed many roads to Paris (the OECD's headquarters) in particular, and pension and economic viability in general.

The rest of the paper proceeds as follows: Section 2 examines pension policies in the OECD, both as recommended in its latest publication as well as in practice, comparing the experience of Israel, its newest member, with that of Ireland, one of the original founders. Section 3 continues the comparative analysis using two theoretical frameworks, and examines the role of labor in the development and reform of pension policies in Israel and Ireland. Section 4 focuses on the macroeconomic impact of various pension policies, starting from the World Bank's multi-pillar model and proceeding to look at actual impacts of pensions on the economy and financial 
markets in Israel and Ireland, as well as impact of the financial crisis on pensions in these two countries. Section 5 concludes.

\section{Pension Policies}

\subsection{The OECD's Pensions at a Glance 2009}

The OECD's Pensions at a Glance 2009 report is the third edition in the series. It looks at the state of pensions of the organization's 30 member countries (as of May 2009), and examines the effects on these pension systems of the financial and economic crises. It also looks at oldage poverty, pension reforms, and voluntary private pensions.

The report acknowledges the heavy impact of the financial crisis in 2008 on private pensions, which lost $\$ 5.4$ trillion, equivalent to $23 \%$ of their aggregate value. Public pensions have also been impacted, both by longer demographic trends as well as by the crisis's indirect effects through lower earnings and higher unemployment [1].

The effects differ according to their impact on specific groups. Young people are projected to be less affected than those near retirement. Private defined-contribution plans, followed by private defined-benefit plans, suffered much more than public pension plans. The latter have not been directly affected, but the effects of the financial crisis cascaded into an overall economic crisis which placed recessionary pressures on wages and employment (leading to lower contributions and perhaps more early retirements).

The report also highlights the overall shift in the private pensions sector from defined-benefit (DB) occupational plans to defined-contribution (DC) plans in the OECD. The U.S. has made the earliest shift, increasing the ratio of occupational-plan members covered by a DC plan from $32 \%$ in 1980 to $71 \%$ in 2003 ; the same ratio increased in Canada from 14\% in 1993 to $24 \%$ in 2003 and in Ireland from under 40\% in 1999 to $50 \%$ in 2005; coverage under DB private-pension schemes in the UK dropped from $23 \%$ in $1998-1999$ to $12 \%$ in $2002-2003$; and by 2006, both of Sweden's largest occupational pension plans (for white-collar and blue-collar workers) have been fully converted to defined-contribution [1].

In evaluating policy responses to the crises in its report, the OECD notes with alarm that "the losses incurred in private pensions have already led to pressures to allow people to switch back into the public scheme" [1]. It argues against such policies, claiming that they will destabilize the pension system. It further downplays concerns about investment risks as short-term thinking, emphasizing instead more long-term risks such as demographic changes and fiscal sustainability. It is quite remarkable, and a testament to the OECD's ideological bent, that in the face of heavy losses by private pension funds in the recent financial crisis and the resulting increases in oldage poverty, it still recommends continuing austerityreforms of pension systems, mostly involving retrenchment and privatization.

Some of the recent reforms mentioned and lauded by the OECD report are the introduction of DC plans in Mexico, Poland, Hungary and Slovakia, cutting life-time benefits in 16 OECD members by $16 \%$, reducing civilservice pensions for early retirement in Ireland, and increasing retirement ages in 14 countries [1].

\subsection{Israel's Accession to the OECD}

The OECD was created in 1961 as a successor to the Organization for European Economic Co-operation (OEEC) which was set up in 1947 for the reconstruction of Europe under the Marshall Plan. The OECD's mission has been "to help its member countries to achieve sustainable economic growth and employment and to raise the standard of living in member countries while maintaining financial stability —all this in order to contribute to the development of the world economy" [2].

Until recently, the organization consisted of thirty countries; in 2010, Chile, Slovenia and Israel became the newest Member Countries, bringing the total to thirtythree. The accession process normally involves the following steps:

1) An OECD resolution to open discussions with a potential member;

2) Approving a road map for the new member's accession to the organization;

3) A meeting of numerous OECD specialized committees to review the country's suitability in various aspects;

4) A formal invitation to join;

5) Signing of an accession agreement and accepting the OECD's legal instruments by the candidate country;

6) Signing the OECD convention.

Given the organization's prestige and the economic benefits (both real and perceived) of membership in this "rich-man's club", countries are obviously interested in joining. In March 2006, Israel's Ministry of Finance published an 80-page document entitled Israel: Ready for the $O E C D$. It describes in detail "Israel's progress in meeting the international objectives and best practices pursued by OECD members" as well as its "activities in OECD bodies during the years 2004-2005”, at the time when Israel was already "a full participant, regular observer, or ad-hoc observer in 50 OECD working bodies" [3]. 
The OECD adopted a resolution on 16 May 2007 on "enlargement and enhanced engagement" to begin open discussions for membership with Israel, as well as with Chile, Estonia, the Russian Federation and Slovenia. Israel's roadmap for accession was approved on 30 November 2007, detailing the process the country needed to go through, including review by 18 OECD committees of issues such as investments, fiscal affairs, environment, corporate governance, financial markets, insurance and private pensions, competition, and consumer policy (Israel had already been an observer at the OECD's Insurance and Private Pensions Committee since 2005) [3]. The process took over two years, and on 10 May 2010 Israel was officially invited to become a member of the OECD. It signed the accession agreement on 29 June 2010 and became a member on 7 September 2010.

In terms of substance, a country wishing to join the OECD is expected to show that it shares "fundamental values and like-mindedness" with the organization, including "adherence to open and transparent market economy principles" [4]. More specifically in regards to pensions, Core Principle 3 of the OECD Recommendations on Occupational Pensions says such pensions should be fully-funded, and that unfunded, pay-as-you go plans "should generally be prohibited" [5]. This is in line with the trend towards privatization and overall retrenchment described in the above discussion of Pensions at a Glance 2009. Israel's pension-system history, however, tells a more complex story.

\subsection{A Brief History of Israel's Pension System}

A former British Mandate territory, Israel became independent on May 14, 1948. Like many of Israel's economic, social and political institutions, its trade-unions organization - the Histadrut-was created well before independence, in 1920, while still under British rule. Today the Histadrut covers about a third of the population, and roughly $85 \%$ of wage-workers.

The retirement system in Israel has three pillarsuniversal social security (Old Age Allowance, OAA), an income-supplement (means-tested), and individual pension fund savings [6]. Before 1995 pension saving for retirement in Israel consisted of occupational pension funds (defined-benefit). Workers in the public sector, large banks and utilities were given similar benefits in programs funded by employers (there was no employee contribution). Part of the salary not covered could be deposited in a private savings account (for at least 15 years). The government provided tax breaks and subsidized returns.

These funds were closed in March 1995 to new members, together with a reduction in benefits for current members. New defined-contribution funds were introduced, but the government still subsidized $70 \%$ of the returns and guaranteed the other 30\% (at a 3.5\% rate).

The retrenchment process continued in 2002-2003. Cuts in public spending on pensions were made in 20022003, consisting of increasing retirement ages and reducing the real value of payments by the National Insurance Institute (NII). Government-guaranteed returns were dropped in 2002. In 2003, the retirement age was raised for both men (from 65 to 67) and women (from 60 to 64). Early retirement benefits were cut and conditions became stricter. In 2005-2006, however, the cuts were reversed due to adverse effects on old-age poverty, but because wages have since increased faster than pensions, the "relative incomes of those with no other source of income were still below the 2002 level in 2007" [7].

The private pension system in Israel is under the supervision and regulation of the Ministry of Finance, Capital Market Insurance and Savings Division (CMISD). The assets are managed by external entities, not employers or banks. They are "set up as limited companies holding insurance licenses and are entitled to operate solely in two areas of activity: pension fund and provident fund management” [7]. The five main private pension-saving types are described schematically in Table $\mathbf{1}$.

\subsection{Recent Developments in Israel}

By 2008 the aged population (65+) in Israel comprised around $10 \%$ of the population, as compared to the OECD average of 15\%. Large cohorts of people born after 1945 are about to retire, however, and the old-age dependency rate in Israel is projected by the OECD to increase from $19 \%$ in 2000 to $35 \%$ in 2050 [7].

About half of the workers in Israel before 2008 were covered by private pensions, with fund balances equaling nearly a third of GDP. Life insurance firms held balances equal to an additional 20\% of GDP [7]. Workers could choose between lump-sum products (pension funds and life polices) and annuities.

In 2007, the Histadrut signed an agreement with employers' organizations mandating a pension for every employee, regardless of union membership or coverage by a collective agreement. Employers would contribute $10 \%$ while employees would pay in 5\% [6]. Pensions became compulsory as of 1 January 2008 (for workers with income up to average wage), and coverage increased to $66 \%$. All new pension funds pay annuities, with the exception of people making $60 \%$ of the average wage (who can choose a lump-sum instead) [7]. Workers now also had a choice of saving vehicles (pension fund, provident fund or a life insurance policy), a choice previously made by unions or employers [7]. 
Table 1. Israel's five main private pension savings types.

\begin{tabular}{|c|c|c|c|}
\hline Accrual & Benefit & Investment & Comments \\
\hline \multicolumn{4}{|c|}{ Old pension funds (until 1995)—DB } \\
\hline $\begin{array}{l}2 \% \text { of earnings for each year of } \\
\text { service }\end{array}$ & $\begin{array}{l}\% \text { accrued of last three years } \\
\text { before retirement }\end{array}$ & $\begin{array}{l}30 \% \text { of assets in } \\
\text { non-tradable } \\
\text { government } \\
\text { bonds }\end{array}$ & $\begin{array}{l}\text { Actuarial deficits in the } 80 \text { s, closed in } 1995 \text { to new employees, cuts } \\
\text { in benefits. A compromise reached where the government will pay } 80 \\
\text { billion shekels over } 35 \text { years, with the participants responsible for the } \\
\text { rest of the liabilities. }\end{array}$ \\
\hline \multicolumn{4}{|c|}{ New pension funds (since 1995)_-Pseudo-DC (savings converted into annuity) } \\
\hline $\begin{array}{l}\text { Up to double average earnings, } \\
\text { employees contribute } 5 \%-5.5 \% \\
\text { and employers } 11 \%-14.3 \%\end{array}$ & $\begin{array}{l}\text { Depends on savings and fiscal } \\
\text { criteria (e.g. death of } \\
\text { members leading to surplus) }\end{array}$ & $\begin{array}{l}30 \% \text { of assets in } \\
\text { non-tradable } \\
\text { government } \\
\text { bonds }\end{array}$ & $\begin{array}{l}\text { Benefits cannot be taken before age } 60 \text {; new pension funds must } \\
\text { provide members with disability and survivor insurance. }\end{array}$ \\
\hline \multicolumn{4}{|c|}{ New general pension funds (since 1999)—_Retirement savings only (not disability and survivors) } \\
\hline \multicolumn{4}{|c|}{ For savers with earnings of more than double the average } \\
\hline & $\begin{array}{l}\text { Capital returns proportional to } \\
\text { members' shares in assets of } \\
\text { fund }\end{array}$ & $\begin{array}{l}\text { Only govern- } \\
\text { ment bonds }\end{array}$ & $\begin{array}{l}\text { Lump-sum after } 15 \text { years allowed until } 2005 \text {. Since then, only at } 60 \\
\text { with a minimum amount withdrawn as annuity. }\end{array}$ \\
\hline \multicolumn{4}{|c|}{ Life insurance - Policies for disability and survivors may have a savings part. } \\
\hline & & \multicolumn{2}{|c|}{$\begin{array}{l}\text { Assets managed by external limited companies (not employers), limited to managing } \\
\text { pensions funds and provident funds. }\end{array}$} \\
\hline
\end{tabular}

After the financial crisis began, a compensation plan was created by Israel's government for workers near retirement $(57+)$ who lost money in their DC funds since November 2008. By comparison, "no OECD country [at the time] bailed out workers who had lost money through saving in voluntary occupational or individual schemes" [7].

On 7 September 2010, on the eve of the Jewish New Year, the Histadrut and employers' organizations signed another agreement, increasing employer contributions to pension funds by $2.5 \%$ a year starting in 2010 . The Histadrut chief hailed the agreement as proof that workers benefits can be increased. The employers' organizations chairman described this increase as a real show of concern for employees in all sectors. The main beneficiaries would be new employees or low-wage earners (or minimum-wage earners) not covered by collective agreements (and receiving only a $7.5 \%$ pension contribution from their employer). The new agreement would increase the $10 \%$ employer contribution to $17.5 \%$ by 2014 . Pension funds would receive hundreds of millions of shekels in further funds as a result.

\subsection{Ireland's Pension System}

Ireland was one of the 20 original founders of the OECD, signing its Convention on 14 December 1960. It serves as a good contrast to Israel, since it has pursued clear neoliberal policies in general and with regards to pensions in particular.
According to the OECD, Ireland's public pension spending in 2006 was less than half of the OECD's average (as \% of GDP), at only 3.4\% [1]. While the proportion of elderly in Ireland (at $17.7 \%$ ) is lower than the OECD average (23.8\%), more than $30 \%$ of its pensioners live in poverty (higher than the OECD average, and third-highest of its members) [1].

Contributory pensions were first introduced in Ireland in 1961. The current public pension has a basic flat rate component, and a means-tested element targeted at lower income pensioners. Around half of Irish employees have private occupational pensions. These are split more or less evenly between defined-benefit and defined-contribution plans. The DB plan pays a portion $(1 / 60)$ of the last salary for every year of work, calculated by the OECD as equivalent to "a contribution rate of $1.67 \%$ " [7]. If people also have the public pension in addition, it is deducted from their entitlement. Occupational DC plans have an average of $10 \%$ of earnings contribution rate. There is no early retirement allowed. Ireland is also one of the only two countries in the OECD (as of May 2009) to not mandate a second-tier pension (the other country is New Zealand) [7].

There has been an intense debate in Ireland about the relative merits of DC and DB plans. Some think that "the sustainable PAYG is superior, delivering pensions of the order of one-fifth higher for the same level of contribution due to lower administrative costs" [8], whereas the DC plans understate pension cost by ignoring investment risks. Others, such as the OECD, support moving to- 
wards personal retirement savings accounts, and suggest "linking the standard retirement age to longevity" and tightening "the link between the pension and years of contributions" [9].

The government of Ireland published a Green Paper on Pensions in 2007, weighing various reform options. While generally criticizing the existing public system as not sustainable, it also expressed concerns about the decline in DB pensions, warning that "retirement benefits [under DC schemes] are too low" and that a move to DC plans involves "a change in the allocation of risks from employers to employees" [10]. The same document also suggested that DC plans may lead to inadequate income, predicting that "most DC members are unlikely to have a retirement income equal to, or greater than, the NPPI target" [10], referring to the standard aimed at by the National Pensions Policy Initiative.

\section{Comparative Analysis}

Having looked at the details of pension policies in Israel and Ireland and tracked recent changes in those policies, it is useful to look at these two countries through the lens of several theoretical frameworks relevant to understanding differences in pension systems and policies.

\subsection{Israel vs. Ireland Based on Pampel and Williamson's 5 Perspectives}

In their book Old-Age Security in Comparative Perspective, John Williamson and Fred Pampel discuss five theories for understanding policy development in the area of old-age security and pensions. They emphasize throughout the book that, in most cases, no single theory is sufficient and each has its merits and drawbacks, depending on the specific context of place and period.

The first theory, the industrialism perspective, applies particularly well to post World-War II developed countries. It traces both the demand for and introduction of public pension programs in particular and social welfare policies in general to industrialization, technological development, urbanization and the resulting changes in the labor force. This theory views spending on public pensions "as a more or less automatic response to the needs generated by industrialization" [11]. As a result, the drawback of this perspective is that it often ignores or minimizes political forces.

Applying this theory to compare Israel and Ireland, one can use Wagner's law to see whether "the size of the public sector relative to the private sector increases as real per capita income increases” [11]. Figures 1 and 2 show the trends of public spending as \% of GDP and per capita income, respectively, for Israel and Ireland for all available years.

While neither country began its industrialization in the 1960 s or 1980s, the data available constrain our analysis to these starting dates. Ireland actually had a lower real per-capita income in 1960, but has since overtaken Israel dramatically. By 2009 Ireland's income of \$36,712 was $45.3 \%$ higher than Israel's \$25,268. In terms of public spending, however, Ireland has been far more conservative. Its government spending as \% of GDP peaked at $21 \%$ in 1980-1981, and has since fallen to a level of around $15 \%$. Israel peaked at $43.4 \%$ in 1975 , and also declined but only to about $25 \%$ currently. It appears that the country that has had less dramatic income growth managed to maintain a more generous public spending than its counterpart.

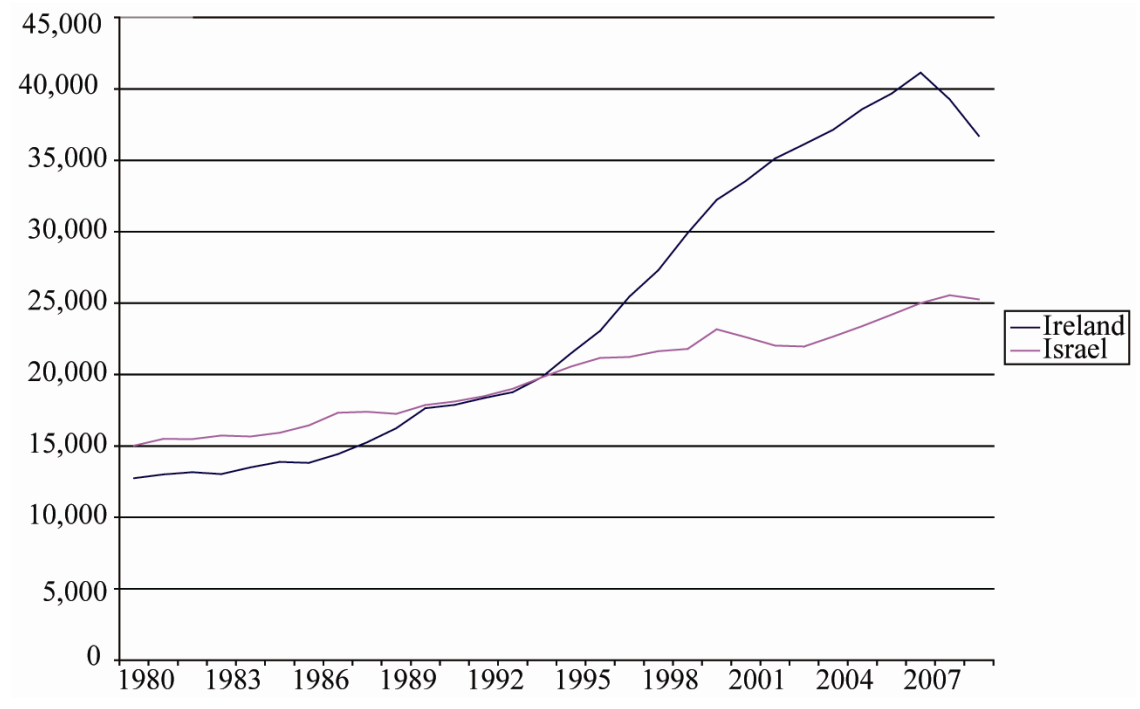

Figure 1. GDP per capita, PPP (constant 2005 international \$). World Bank, November 2010. 


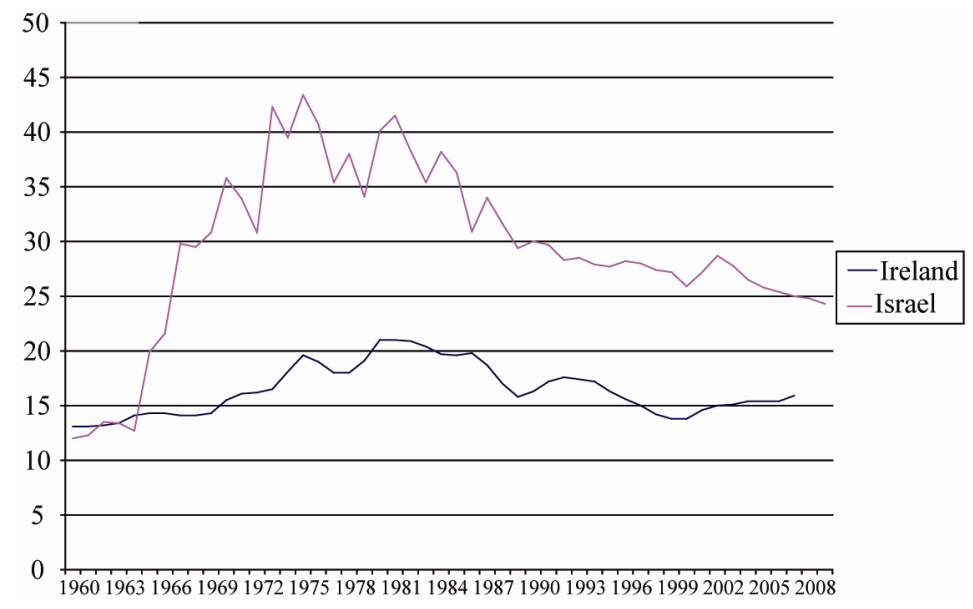

Figure 2. General government final consumption expenditure (\% of GDP). World Bank, November 2010.

The social democratic perspective places more weight on a democratic struggle between classes to use the government to their benefit. It stresses "the role of organized labor and leftist political parties as determinants of how much influence the working class is likely to have" [11]. Indicators for measuring this include social spending as a share of GNP, prevalence and strength of unions, and the number of years a leftist party is in power.

Looking at the trends for Israel and Ireland for these three indicators, one gets a clear sense of contrast. Figure 3 shows social expenditures as \% of GNI.

Israel has increased its social expenditures as a percentage of GNI from $0.3 \%$ in 1970 to $1 \%$ in 1992 and to $1.5 \%$ in 2007 . The Labor party has been in power in Israel all the way through 1977, after which the right-wing Likud party came to power, until another reversal in 1984. Power changed hands several more times, includ- ing a few unity governments. In the period shown in Figure 3 below, Labor was in power 1992-1996, Likud from then until 1999, One Israel (leftist) 1999-2001, Likud 2001-2006, and finally Kadima (center) 2006-2009. This political pattern does not match the data very well, implying perhaps a broad support for social spending across party lines (Likud's rise to power in 1977 does actually fit the decrease in overall government expenditure shown in Figure 1 above).

Ireland has shrunk its social expenditures from 1.4\% of GNI to 0.8\% from 1992 to 2007. In 1992 its government was shared between the Republicans (Fianna Fáil), Progressive Democrats and Labor though a Republican was head of state (Taoiseach). In 1994 power was shared by three parties: Fine Gael (right), Labor and Democratic Left. From 1997-2007 both the Republicans and Progressive Democrats were in power. In all the years since

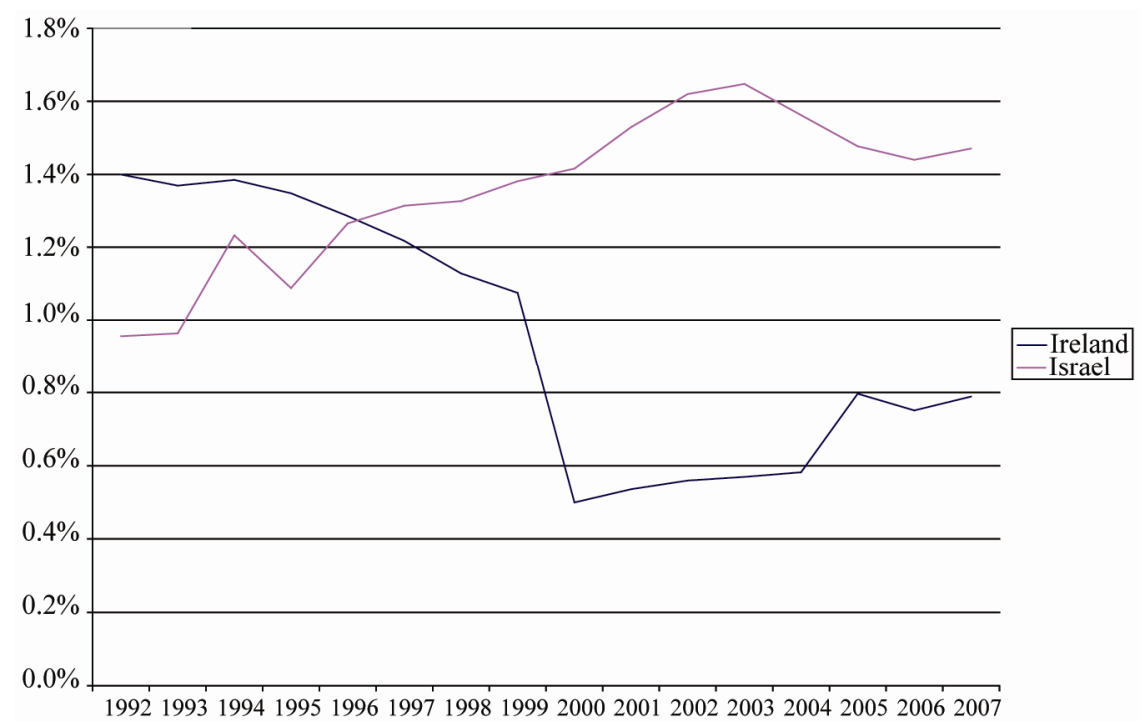

Figure 3. Government expenditure on social protection as \% of GNI. UN Statistics Division, November 2010. 
1997 a Republican was Taoiseach. This dominance of the right may explain more closely in Ireland's case the constant decrease in social spending.

Union membership in Ireland has also dropped recently. According to the Central Statistics Office, in 1994 over 45\% of employees were members, while in 2004 only about a third belonged to a union [12]. In Israel, membership of the Histadrut dropped from 79\% of workers (wage earners and salaried) in 1981 to $49 \%$ in 1996. Five percent of workers belonged to other unions, so total union membership was higher than the above figures. However, before 1980 membership of unions is estimated at $80 \%-85 \%$, so there was a clear decline [13]. This fits the social-democratic perspective, and explains both the long-term weakening of labor and pensions in Ireland, as well as the move in 1995 from DB to DC plans and retrenchment trends in Israel until 2007 (though some parts were later reversed as shown above).

The neo-Marxist perspective is less optimistic regarding the merits of the democratic process and the prospects for workers' political power. It assumes that the ruling class controls the government in industrialized countries. This theory and its proponents have mixed views about public pensions. Such policies are often seen as a means to control and co-opt workers, with little or no redistributive effects. The theory explains fiscal crises by the attempts of governments to "socialize the costs of production while privatizing profits" [11]. Israel does not seem to fit this story, since it started with 29 years of Labor party rule and a near monopoly of the Histadrut in pension and health-care provision. The later pull-andpush process with regards to pensions only proves the relative strengths of various factions, rather than exhibiting any control of government by the elite. In Ireland, however, the history has been far clearer, with the introduction of contributory schemes in 1961, the absence of an early retirement option, the high elderly poverty rate and the overall conservative approach of government and employers to pensions.

The neo-Pluralist perspective goes beyond political parties and classes and emphasizes civil society and interest groups. This environment can at times facilitate policy compromises, but at other times leads to political stalemates. One such group which is often powerful is the aged population. An important implication of the neo-pluralist perspective is that "pension policy is inherently political", in clear contrast to the industrialism and neo-Marxist perspectives "which see pensions as a more automatic response to industrial and demographic changes or changes in productive relations" [11].

Looking at the size of the elderly-group over time, there does seem to be a sizeable increase in the percentage of the elderly in Israel, from 3.6\% in 1950 to over
$10 \%$ in 2005. In Ireland the increase has only been from $9.2 \%$ to $11 \%$. Thus the neo-pluralist theory may well explain the greater political weight of the aged in Israel than in Ireland, and the resulting effect on pensions described above.

Finally, the state-centered perspective sees the government as having some autonomous power in policy making, rather than being under the control of classes or interest groups. Some aspects of state structures are the existence and degree of democracy, the centralization or de-centralization of government, and corporatist theories. Corporatism can take democratic forms (e.g. Sweden and Austria) in which case it facilitates negotiations and cooperation between capital and labor. When corporatism is authoritarian (e.g. fascist Italy), however, the government is more in control and attempts to retain and enhance its own power "while at the same time decreasing the influence of various interest groups, particularly organized labor" [11]. A highly developed and specialized group of civil service can serve as "technocratic experts who have a substantial impact on program formulation and reform due to their specialized knowledge" [11].

In a review of organized labor in Israel, Cohen et al. suggest that the trade unions in Israel were exceptional before 1980 due to both "extensive ownership of economic activity" as well as the part they took in the process of nation building [13]. The economic power of the Histadrut (which represented up to $85 \%$ of workers in the 1970s) included "control over the pension market" and an "almost monopolistic position in the provision of health care" [13]. It should be remembered that Israel was founded with a strong social-democratic vision, including experiments such as the Kibbutzim (collective agricultural communities), free healthcare and education, and mandatory military conscription. Politically it received support first from the USSR and then from France, until the six-day war in 1967. Since then, and under a growing American support and influence, Israel's economy and society have been trending to the right, breaking away (albeit gradually at first) from socialist ideals towards Anglo-style capitalism.

Cohen et al. describe the consequences of this "transition from a system that most resembled corporatist systems, sharing features with countries such as Austria, Germany and Belgium, to a much more pluralist system, hence more similar to that in the United States" [13]. These include decreasing union membership rates, lower collective bargaining coverage, union decentralization, and an increase in representation by non-unions. The pre80s system was a tri-partite arrangement between the Histadrut, the ruling Labor party and employers' organizations. The political alliance between the Histadrut and the Labor governments (in rule continuously from inde- 
pendence in 1948 until 1977) allowed "a strong interventionist position taken by the state" [13] in negotiations on wages and work conditions.

Due to the loss of political power to the Likud party in 1977, as well as globalization, increased share of migrant workers, "decline of traditional unionized industries, and increased workers' heterogeneity” [13], the Israeli corporatist system started to fall apart, weaken and decentralize in the late 1970s. Worker membership in the Histadrut fell from a peak of $79 \%$ in 1981 to $45 \%$ in 2000 (with coverage of only $56 \%$ of wage workers). Independent unions gained from the Histadrut's losses, covering about $20 \%$ of workers by 2000 (especially professional unions such as teachers, academics, doctors and journalists). In general, union membership is still high in public sector industries (health, education, welfare and utilities) and some private ones (manufacturing and banking). Agriculture and construction, dominated by low wages and many migrant workers, are "predominately nonunion” [13].

\subsection{Israel vs. Ireland Using Weaver's Three R's}

Another insightful theoretical perspective with which to compare and contrast pension policies in different countries is that of Kent Weaver. In both Cutting Old-Age Pensions and The Politics of Public Pension Reform, Weaver details both the pressures faced by governments to cut pensions, as well as their strategies to reduce blame and minimize political backlash. This approach implies that pension policies and reforms are not purely economic decisions, but have a large and quite complicated political context in which they need to be viewed.

The first political aspect of pensions is the relative po- litical strength of the elderly in many countries. This is a "large, politically active group, and they are viewed sympathetically by the rest of the electorate" [14]. Young people also sympathize with retirees, both because one day they will be in their place, and because any cuts in pensions might increase their own share of the burden in supporting older relatives. As is shown in Figure $\mathbf{4}$ below, the proportion of elderly to total population in Israel nearly tripled from 1950 and 2005, thus increasing the potential for pressure in favor of maintaining or expanding pensions.

At the other end of the political debate on pensions are various pressures on governments to restrain or cut spending. These include demographic factors such as ageing populations, budget deficits, and political resistance to (at times bordering on demonization of) raising taxes. Weaver also mentions the effect of lower poverty rates among the elderly (compared to the general population), which can create a perception, common in the U.S. and Canada (and perhaps other OECD countries), that "substantial pension benefits are received by persons who are relatively well off and do not 'need' them” [14]. Another source of increased political pressure is the neoliberal philosophy that people can manage their savings (for retirement and in general) better than the government. This has manifested itself in increased attempts to replace DB with DC plans, and to create or expand personal savings accounts.

The problem with this philosophy is that it gives people too much credit for being able to "do-it-yourself". Teresa Ghilarducci examines this myth, among others, in her book When I'm Sixty-Four: The Plot against Pensions and the Plan to Save Them. In addition to stagnating growth in pension coverage, she mentions three other

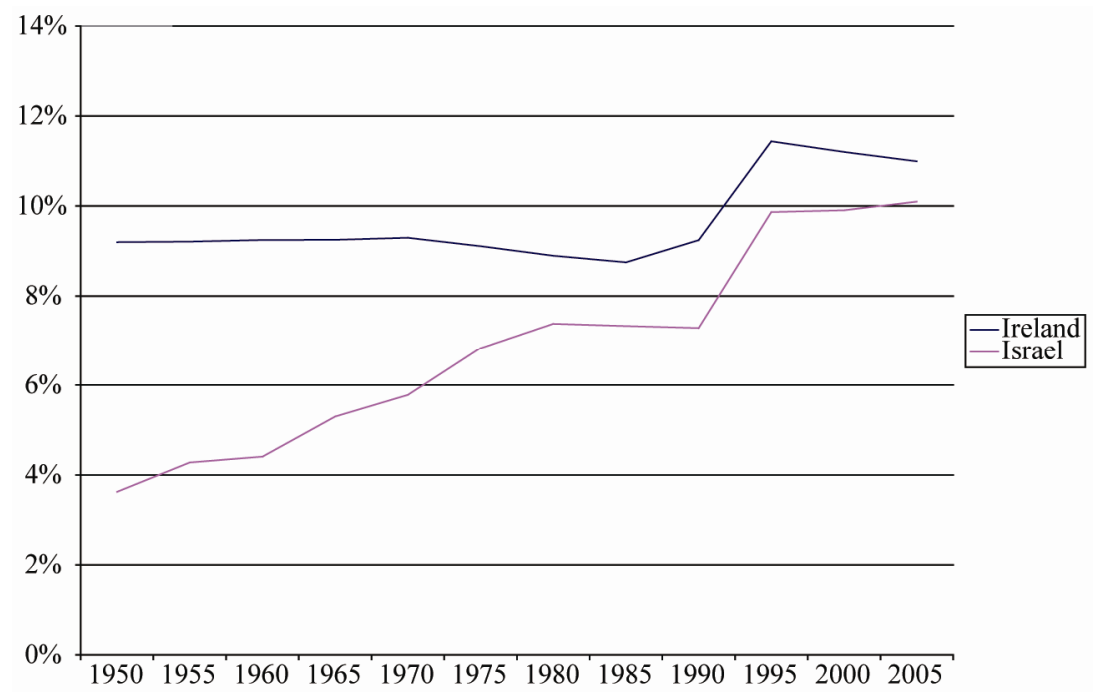

Figure 4. Population 65 and over as \% of total population. UN Population Division, November 2010. 
consequences of shifting from DB to DC plans. These three "i's" include inefficiency (low income security to savings ratio), inadequacy (of savings for retirement) and inequality (workers bearing more risk than employers, middle-class workers more than upper-class ones). People tend to be myopic about both their longevity and future income, and as a result are "unsuited and unable to earn the maximum return on their pension savings when individual accounts are the vehicle to do so because of high and hidden management fees, the lack of investment experience, and the difficulty of saving enough to eliminate the downside risk of not having enough to retire on" [15]. It is also common sense that, in a modern, specialized economy, the average worker does not have the time, skills and experience of an investment specialist or actuary in planning for retirement.

The three options available to government facing such pressure are, according to Weaver's framework, retrenchment, refinancing or restructuring, which can be used separately or in combination. The first option, retrenchment, can take the form of cutting pension benefits, reducing inflation adjustments, raising the retirement age, forbidding or restricting early retirement, and making criteria for receiving various benefits stricter. The second option, refinancing, seeks rather to increase pension system revenues. This can happen through increasing the tax rate or the tax base, channeling government (general) revenues into pension systems, and adding new groups previously not paying payroll tax towards pensions. The final option, restructuring, can work through abolishing existing universal pension pillars, and making private, occupational pensions mandatory as a substitute for public-pension pillars.

Various strategies have been used by reformers to reduce the blame associated with each of these steps. Weaver mentions delaying, phasing-in, use of complicated formulas to reduce transparency, targeting weak groups, and grandfathering of "current retirees and the near-elderly into [the] current system" [14]. All of these are meant to reduce or shift the blame for pension cuts and minimize the political retaliation by voters (at times by completely shifting it away to the next administration).

Israel has experienced some retrenchment and restructuring as described above, notably in the closing of DB plans to new members in 1995, cutting benefits and raising retirement ages in 2002-2003. It also used some refinancing by dropping initial government guarantees for the DC plans. Ireland has also seen retrenchment and refinancing in the ever-decreasing share of public spending to GNI as shown above. Restructuring has been evident in the relative increase in DC plans at the expense of DB plans.

\subsection{The Role of Labor in Israel vs. Ireland}

Pushing back against retrenchment, organized labor has played a far greater role in Israel than in Ireland. The Histadrut was created in 1920, 28 years before independence, and played a major role in both social and economic development as well as in nation building. As described above, a corporatist tripartite system was at work, centrally determining wages and work conditions and supported by the ruling Labor party until 1977. Some ground was lost later, with the election of Likud to power, and decentralization of collective bargaining. However in recent years, the Histadrut and other unions made great strides in protecting and even expanding pension coverage. Two important examples are the mandating of pensions for every employee since 2008, and the very recent agreement (September 2010) to raise employer contributions towards pensions from $10 \%$ to $17.5 \%$ by 2014.

In Ireland there was never such dominance of laborunions, and recently membership has further dropped from $45 \%$ to around a third as described above (compare with Israel's pre-1980s level of $80 \%$ - 85\%). The struggle on the politics and economics of pensions in Ireland seems to have been fought more through political parties (cf. the Green Paper mentioned above) than through collective bargaining.

\section{Macroeconomic Impact}

Having looked at pension policies in relation to workers, employers, unions and governments, it is useful to widen the scope and examine the impact of various pension policies on the economy as a whole, both in theory as well as in the two countries discussed in this paper. The World Bank's multi-pillar model can serve as a theoretical starting point.

\subsection{The World Bank’s Three Pillars}

The World Bank's report on averting old-age crisis attempts to recommend policies that would both "protect the old and promote growth" (bold in original), as its name suggests. Its diagnosis of the problems in old-age financial-security systems is similar to that of the OECD, citing higher life expectancy and lower fertility and the resulting increases in dependency ratios. It also points out that traditional support systems in developing countries (e.g. extended family care, community and other informal ties) are eroding fast due to "urbanization, mobility, wars and famine" [16]. The philosophy in the report is "to move toward formal systems of income maintenance without accelerating the decline in informal sys- 
tems and without shifting more responsibility to government than it can handle" [16].

This implies a traditional distrust of government's ability to manage pensions, but at the same time the report acknowledges that individuals cannot be depended on completely to save for old-age because of their shortsightedness, lack of sufficient savings instruments, insurance market failures, information gaps and the causes of long-term poverty (insufficient life-long earnings which can only be handled by redistribution).

More generally, the report cites various problems with all single-pillar systems in different settings. Provident funds, for example, are often misused, allowing government easy access to finance at low interest rates, constituting "a hidden tax on labor" [16]. The criticism against occupational pension plans is that "they redistribute in accordance with employer rather than social objectives" [16], and are usually not funded fully. Private savings accounts are at fault since they do not deal with information gaps or long-term poverty.

The recommended solution is a "multi-pillar system". The World Bank recommends separating the three functions of financial security systems for the aged-redistribution, saving and insurance-using three pillars: a small, mandatory public pillar only meant to reduce oldage poverty; a mandatory private saving system; and a voluntary pillar. It also gives separate recommendations on how to get to this system for economies in various development stages, such as young but low-income countries, young and rapidly-aging ones, and older economies that already have well-established public pillars. The latter group includes the OECD, among others, and faces "imminent problems with their old age system" [16]. Solely relying on and expanding the public pillar would result, according to the World Bank, in higher taxes, lower growth, and low returns. The two-stage pre- scription is to start by reforming the public pillar and then create a private one. More specifically, the first step involves "raising the retirement age, eliminating rewards for early retirement and penalties for late retirement, downsizing benefit levels $\cdots$ and making the benefit structure flatter $\cdots$ the tax rate lower, and the tax base broader" [16]. The second step would reallocate contributions from the public pillar to a second private mandatory pillar or raise contributions in the first pillar and channel to them to the second pillar.

The foreseen benefits of the new system would include a closer link between contributions and benefits in the private pillar, enhanced saving and capital market development, and full funded growth, thus having a positive macroeconomic impact. The World Bank also suggests that this multi-pillar system would contribute to risk diversification (since it's mixing private and public elements), leading to improved performance.

\subsection{Impact of Pension Reforms on Aggregate Demand and Macroeconomic Stability}

The World Bank multi-pillar model predicts positive effects on savings and growth of a smaller public pillar and a larger private pillar. Looking at data on gross savings as a percentage of GNI, Figure 5 shows some increase in Ireland over time, though there is a beginning of a decline in 2007, coinciding with the bursting of the housing bubble and the beginning of the financial crisis. According to Eurostat, gross saving in Ireland (as \% of GDP) fell to $16.4 \%$ in 2008 and $11.5 \%$ in 2009 , and is forecasted to further decrease to $10.5 \%$ in 2010 and $11.0 \%$ in 2011.

Israel, on the other hand, maintained a relatively steady proportion of savings to income. Its switch from DB to DC plans in 1995 does not seem to have caused an

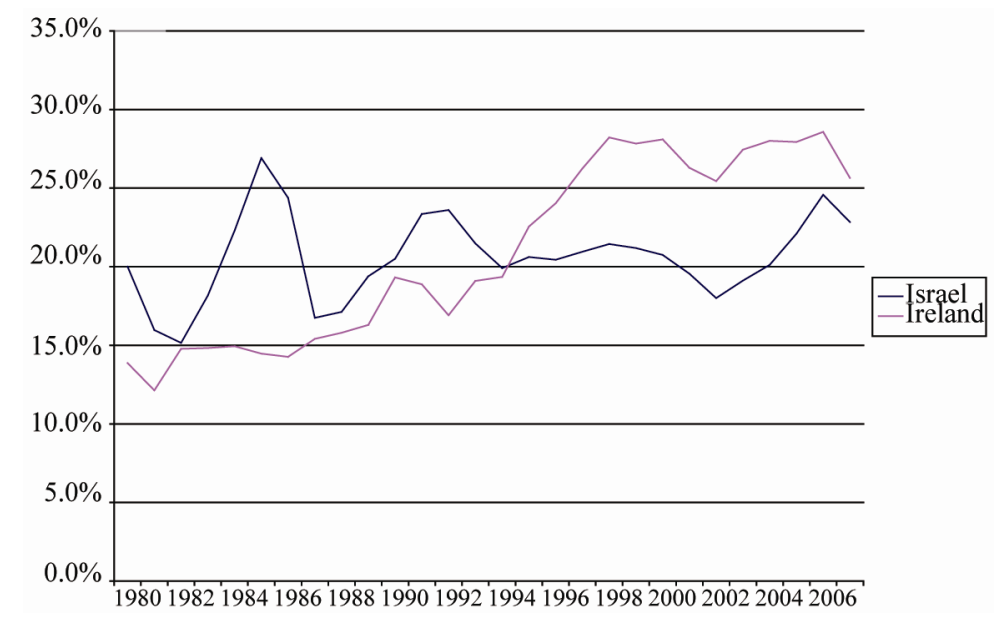

Figure 5. Gross saving as \% of GNI. UN Statistics Division, November 2010. 


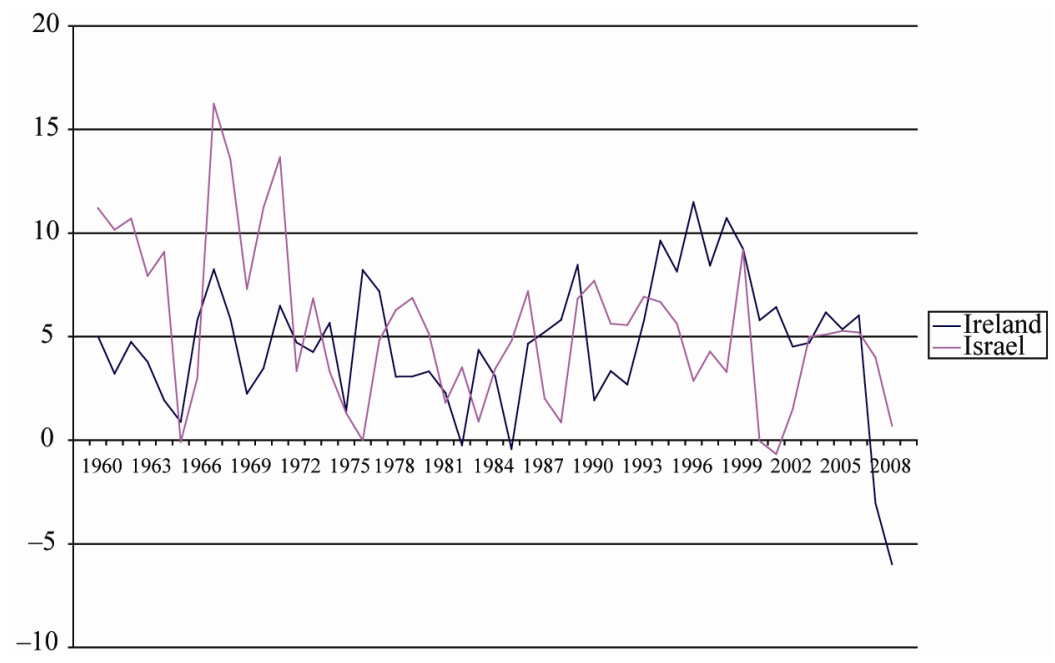

Figure 6. Gross domestic product growth rate. World Bank, November 2010.

increase in the savings rate, as the World Bank model predicted.

Turning to growth, Israel's GDP growth rate has been more stable and more consistently positive than Ireland's since 1961. If anything, Israel's growth rates before its switch to DC plans in 1995 were higher (average annual growth of 3.8\% between 1961 and 1994, compared to $2.5 \%$ from 1995 to 2009).

\subsection{Impact of Pension Reforms on Financial Markets}

The lack of mandatory pension savings in Ireland and the increasing reliance on DC plans as opposed to DB plans has led to shrinking in financial assets under management of pension funds. In Israel, by contrast, the mandatory savings plan and the recent increase in employer contributions from $10 \%$ to $17.5 \%$ (phased in until 2014) are both expected to have large positive effects on fund availability, making financial markets more liquid and increasing the power of labor.

Figure 7 shows the trends based on available data up to 2009 from the OECD's Global Pension Statistics database. Israel's has constantly increased its pension fund assets as a percentage of GDP, while in Ireland the level of assets has fluctuated drastically and suffered major decreases from its peak in 2006.

\subsection{Impact of the Financial Crisis on Pensions, Aggregate Demand and Financial Markets}

Israel has weathered the financial crisis better than most developed countries. This is due in part to a cautious monetary policy and a sound regulatory environment. It can also be attributed in part to the important contribu-

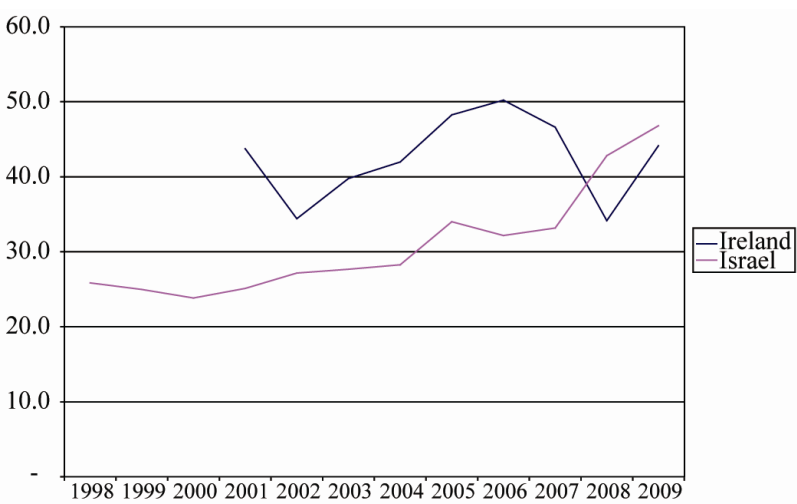

Figure 7. Pension funds' assets as a \% of GDP. OECD, November 2010.

tion of government spending in general, and on pensions in particular, to aggregate demand. As shown above, Israel's spending on government expenditure has been around 25\% of GDP in recent years (compared to Ireland's $15 \%$ ), and it spending on social protection was $1.5 \%$ in 2007 compared to Ireland's $0.8 \%$ of GNI that same year.

As mentioned above, when the financial crisis began, Israel created a compensation plan was for workers near retirement $(57+)$ who lost money in their DC funds since November 2008. No OECD country made a similar move. Among the 30 members of the OECD at the time, Ireland's private pension system suffered the worst investment losses, declining by $37.5 \%$ in real terms in 2008. The OECD explains this by pointing to the composition of pension assets in Ireland, with equities comprising two-thirds of total assets (as compared with 36\% on average in the OECD) [1].

Given that in Ireland private pensions account for a third of all retirement income (the OECD average is un- 
der 20\%), the effects on pension benefits and old-age poverty are severe. Thirty percent of Ireland's retirees are under the OECD poverty threshold (second only to Korea and Mexico) [1]. The safety net for old age in Ireland is also low by OECD standards: the net replacement rate (full-career workers) is $68.4 \%$, seventh from the bottom and well below the OECD average of $82.4 \%$ (contrast with Denmark's 137\%) [1].

Given the higher propensity to consume of people on fixed income, especially those below the poverty line, such a decrease in income can only lead to a large decrease in aggregate demand, thus further depressing the Irish economy (which contracted by $3 \%$ in 2008 and 6\% in 2009, compared with Israel's growth of $4 \%$ and $1 \%$ in the same years, respectively).

\section{Conclusions}

Common (neoliberal) wisdom has it that traditional, public or defined-benefit pension plans are unsustainable due to demographic shifts and fiscal pressures. Organizations such as the OECD and the World Bank have been vocal in promoting defined-contribution pension plans as well as personal retirement accounts as an alternative, positioning this paradigm shift as the only viable alternative for countries to pursue. This paper has compared the experience of Ireland, an original OECD founder and a classical neoliberal example, with that of Israel, the newest member of the OECD. Israel's path to both OECD membership and pension policy balance has been far more complex than the simplistic OECD model, involving active participation of the Histadrut as well as other labor unions, a corporatist (followed by a pluralist) national debate, and a recent strengthening of pensions by mandating coverage for every employee as well almost doubling of employer contributions to occupational pensions plans.

Defying the World Bank model's predictions, these steps have actually led to both stable and positive growth in savings rates, GDP and pension assets. Ireland, by contrast, suffered major losses in its voluntary private pensions (two-thirds of which were invested in equities), large increase in old-age poverty and output contraction. While pension policies may not have directly caused the differential results in the two countries, their impact on aggregate demand has certainly played an important role in the outcomes.

It appears, therefore, that rather than a single path to pension stability and economic growth, countries face various options they can take to ensure positive outcomes for retirees, workers and the economy as a whole. Israel's path to OECD membership has involved some retrenchment, but overall has displayed a collaborative approach between labor, employers and the government, and has resulted in a much more balanced system of pensions than that in Ireland. All roads may lead to Paris, but some are more beneficial than others.

\section{References}

[1] Organisation for Economic Co-Operation and Development, "Pensions at a Glance 2009: Retirement-Income Systems in OECD Countries,” OECD, 2009.

[2] OECD Website, “About OECD: History,” OECD, 2011. http://www.oecd.org

[3] Israel, Ministry of Finance, "Israel: Ready for the OECD," March 2006.

[4] OECD, "Roadmap for the Accession of Israel to the OECD Convention,” C (2007)102/FINAL, OECD Council, 3 December 2007.

[5] OECD, "OECD Recommendation on Core Principles of Occupational Pension Regulation,” OECD Council, 5 June 2009.

[6] A. Brender, "Distributive Effects of Israel's Pension System,” Discussion Paper No. 2009, Bank of Israel Research Department, 10 October 2009, pp. 5-7.

[7] OECD, "OECD Reviews of Labor Markets and Social Policies: Israel,” OECD, 2010.

[8] S. Whelan, "Valuing Ireland's Pension System,” Quarterly Economic Commentary, Summer 2007, p. 55.

[9] OECD, “OECD Economic Surveys: Ireland,” OECD, 2009.

[10] Ireland, Department of Social and Family Affairs (DSFA), “Green Paper on Pensions: Executive Summary,” Dublin, 2007.

[11] J. B. Williamson and F. C. Pampel, "Old-Age Security in Comparative Perspective,” Oxford University Press, Oxford, 1993.

[12] Ireland, Central Statistics Office, "Quarterly National Household Survey: Union Membership 1994-2004,” 2010, p. 1.

[13] Y. Cohen, "The State of Organized Labor in Israel," Journal of Labor Research, Vol. 28, No. 2, 2007, pp. 255-259.

[14] R. K. Weaver, "Cutting Old-Age Pensions,” In: R. K. Weaver, Ed., The Government Taketh Away: The Politics of Pain in the United States and Canada, Georgetown University Press, Georgetown, 2003, pp. 41-43.

[15] T. Ghilarducci, "When I'm Sixty-Four: The Plot against Pensions and the Plan to Save Them," Princeton University Press, Princeton, 2008.

[16] World Bank, "Averting the Old Age Crisis: Policies to Protect the Old and Promote Growth,” Oxford University Press, Oxford, 1994. 